DOI: $10.4274 /$ tpa.46.04

\title{
Ebeveynleri erken koroner kalp hastalığı geçirmiş çocuklarda endotel işlevi ve trombotik sistem değerlendirmesi
}

\author{
Endotel function and thrombotic system evaluation of children \\ whose parents had early onset coronary heart disease
}

\author{
C. Naci Öner, Rukiye Eker Ömeroğlu*, Kemal Nişli*, Taner Yavuz ${ }^{*}$, Helen Bornaun*, \\ Ümit Türkoğlu**, Ümrah Aydoğan*, Aygün Dindar*, Türkan Ertuğrul* \\ Koşuyolu Yüksek Ihtisas Eğitim ve Araştırma Hastanesi, Çocuk Kardiyolojisi Birimi, Kartal, İstanbul, Türkiye \\ *Istanbul Üniversitesi Istanbul Tıp Fakültesi, Çocuk Kardiyolojisi Bilim Dalı, Istanbul, Türkiye \\ **istanbul Üniversitesi, İstanbul Tip Fakültesi, Biyokimya Anabilim Dall, İstanbul, Türkiye
}

\section{Özet}

Amaç: Bu çalışmanın amacı; anne ve/veya babası 55 yaşın altında koroner arter hastalığı (KAH) geçirmiş olan çocuklarda bazı hemostatik ve enflamatuar belirteçlerin düzeylerini araştırmak ve bu belirteçlerin KAH'ın gelişme riskini göstermede etkili olup olmadığını belirlemektir.

Gereç ve Yöntem: Bu ileriye dönük çalışma Fakülte Yerel Etik Kurul izniyle İstanbul Tıp Fakültesi, Çocuk Kardiyolojisi Bilim Dalı'nda yapılmıştır. Ailesinde 55 yaş altında KAH olan 43 sağlıklı çocuk aynı yaş ve cinsiyetteki sağlıklı kontrollerle eşleştirilerek doku faktörü (DF), serbest ve toplam doku faktörü yolu inhibitörü (DFYi), fibrinojen, von Willebrand faktör (vWF) ve yüksek duyarlıklı CRP (hsCRP) düzeyi belirlendi. Verilerin analizi SPSS 10 programı ile student-t ve Mann-Whitney U testleri kullanılarak yapıldı.

Bulgular: Çalışma grubunda vWF düzeyleri kontrol grubuna göre daha yüksek bulundu [116,3 $\pm 52,2$ ve $86,8 \pm 41,4 \mathrm{ng} / \mathrm{mL}$, (p<0,05)]. İki grup arasında DF, toplam ve serbest DFYi, fibrinojen ve hsCRP yönünden istatistiksel olarak anlamlı farklılık saptanmadı.

Çıkarımlar: Özellikle erken yaşta KAH geçirmenin temelinde genetik etmenlerin olduğunun bilinmesine karşın, bizim çalışmamızda ebeveynlerinde erken yaşta KAH öyküsü olan çocuklarda vWF dışındaki hemostatik ve enflamatuar belirteçler bağımsız bir risk etmeni olarak gösterilememiştir. (Türk Ped Arş 2011; 46: 20-5)

Anahtar sözcükler: Doku faktörü, doku faktörü yolu inhibitörü, erken yaşta ortaya çıkan koroner arter hastalığı, fibrinojen, von Willebrand faktör, yüksek duyarlııklı C-reaktif protein

\section{Summary}

Aim: First-degree relatives of patients who have had an acute myocardial infarction prior to age of 55 years have 2-7 times the risk that their peers have. The aim of this study was to investigate some haemostatic and inflammatory markers, in children whose parents had early onset ( $<55$ years) coronary artery disease (CAD), and whether those markers were effective to show CAD risk.

Material and Method: This prospective study was performed in Pediatric Cardiology Department of Istanbul Medical Faculty with the permission of Local Ethic Committee of Faculty. Forty-three healthy children, whose parents had early onset CAD, were matched with age and sex pairs and tissue factor (TF), free and total tissue factor pathway inhibitor (TFPI), fibrinogen, von Willebrand factor (vWF) and high sensitive CRP (hsCRP) were analyzed in both groups. SPSS 10 were performed for analyzing data using Mann-Whitney $U$ and student-t tests. Results: Study group had higher vWF than control group $(116.3 \pm 52.2$ vs. $86.8 \pm 41.4 \mathrm{ng} / \mathrm{mL}), \mathrm{p}<0.05)$. Tissue factor, total and free TFPI, fibrinogen and hsCRP were not statistically different between the two groups.

Conclusions: Although premature CAD is known to have a particularly strong genetic component, this study showed that haemostatic and inflammatory markers except vWF are not independent risk factors of family history of early onset CAD. (Turk Arch Ped 2011; 46: 20-5)

Key words: Early onset coronary heart disease, fibrinogen, high sensitive C-reactive protein, premature coronary heart disease, tissue factor, tissue factor pathway inhibitor, von Willebrand factor

Yazışma Adresi/Address for Correspondence: Dr. C. Naci Öner, Koşuyolu Yüksek İhtisas Eğitim ve Araştırma Hastanesi, Çocuk Kardiyolojisi Birimi, Kartal, İstanbul,Türkiye E-posta: nacioner@yahoo.com Geliş Tarihi/Received: 01.03.2010 Kabul Tarihi/Accepted: 09.08.2010 Türk Pediatri Arşivi Dergisi, Galenos Yayınevi tarafindan basilmıștir. / Turkish Archives of Pediatrics, published by Galenos Publishing 


\section{Giriş}

Erişkinlerde aterosklerozun yol açtığı koroner arter hastalığı $(\mathrm{KAH})$ tüm dünyada, özellikle batı ülkelerinde önde gelen ölüm nedenlerindendir (1). Türk Kardiyoloji Derneği'nin öncülüğünde 1990 yılından itibaren yürütülen çalışmanın verilerine göre; Türkiye'de iki milyon KAH olgusu olduğu ve bunların her yıl yaklaşık 65 000'inin KAH'tan öldüğü tahmin edilmektedir (2). Son ylllarda KAH patojenezinde rol oynayan genetik ve çevresel etkenler araştırmaların ilgi odağı durumuna gelmiştir. Erken yaşlarda geçirilmiş KAH'ta genetik etmenler daha ön planda olabileceğinden, ailesinde erken yaşta $\mathrm{KAH}$ olan çocuklar, altta yatan biyokimyasal ya da hematolojik bozukluklar yönünden araştııımışlardır $(3,4)$. Ortaya çıkarılan biyokimyasal ya da hematolojik risk etkenleri belirlendiğinde, çocukluk yaşlarından başlayarak birincil ve ikincil korunma planlarının yapılması da mümkün olacaktır $(5,6)$.

$\mathrm{Bu}$ çalıșmanın amacı ailesinde erken yașlarda $\mathrm{KAH}$ öyküsü olan sağlıklı çocuklarda hastalığın oluşumunu öngörecek hemostatik ve enflamatuvar belirteçlerden doku faktörü (DF), serbest ve toplam doku faktörü yolu inhibitörü (DFYI), fibrinojen, von Willebrand faktör (vWF) ile yüksek duyarlıklı C-reaktif protein (hsCRP) düzeylerini saptayarak, bu belirteçlerin $\mathrm{KAH}$ aile öyküsü nedeni ile risk altında olan çocuklarda artıp artmadığının belirlenmesidir.

\section{Gereç ve Yöntem}

Bu çalışma İstanbul Üniversitesi, İstanbul Tıp Fakültesi, Çocuk Kardiyoloji Bilim Dalı'nda ileriye dönük olarak tasarlandı ve Eylül 2005 ile Eylül 2007 arasında yapıldı. Çalışmaya Çocuk Kardiyoloji Polikliniği'ne üfürümü olduğu için getirilen ve ekokardiyografik incelemesinde bir anormallik saptanmayarak masum üfürüm tanısı almış, öyküsünde ebeveynlerinde erken dönemde ( $\leq 55$ yaș) KAH saptanan, 5-18 yaşlar arasında 43 olgu alındı. Olguların 14'ü erkek $(\% 32,6)$ ve 29 'u kı (\%67) idi. Bu olgular aynı yaş ve cinsiyetteki sağlıkı kontrollerle eşleştirilerek DF, toplam ve serbest DFYi, fibrinojen, vWF ve hsCRP düzeyleri belirlendi. Çalışmaya alınmadan önce çalışma ve kontrol grubundaki tüm olgular ve aileleri araştırmaya ilişkin ayrıntılı olarak bilgilendirildi ve onam formu imzalatıldı. Ayrıca araştırma Fakülte Yerel Etik Kurulu'nca onaylandı.

Çalışma ve kontrol grubundan ayrıntılı öykü alınarak kronik hastalıklarııın olmadığından ve sigara içmediklerinden emin olundu. Daha sonra ayrıntılı fizik muayene yapılarak, vücut ölçümleri (ağırlık, boy), kan basıncı ölçümleri yapıldı. Yukarıda söz edilen hastalıkları olanlar, sigara içenler ve kan alındığı gün akut hastalı̆ı̆ bulunanlar çalışmaya alınmadı. Çalışmaya alınan tüm hastaların, akşam yemeğini izleyen bir gecelik (10-12 saatlik) açlık sonrası sabah kan örnekleri alındı. Doku faktörü, serbest ve total DFYi "Imubind-tissue factor" kiti (American Diagnostica Inc, US) kullanılarak ELX-800 Biotech-Instruments Inc. ELISA okuyucuda ölçüldü. Serum hsCRP Roche İntegra-800 otoanalizöründe türbidimetrik yöntemle ölçüldü. Bu ölçümler Çocuk Biyokimya Laboratuvarı'nda yapilırken plazma fibrinojen ve vWF Çocuk Hematoloji Laboratuvarı'nda ölçüldü. Fibrinojen "Fibri-prest automate 2" kiti (Diagnostica, Stago Inc, France) kullanılarak Clauss yöntemiyle, vWF "vWF ELISA" kiti (Diagnostica, Stago Inc, France) kullanılarak belirlendi.

Çalışmada elde edilen veriler SPSS 10,0 programı kullanılarak değerlendirildi. Değerlendirmede; tanımlayıcı istatistiksel yöntemlerin yanı sıra, niceliksel verilerde normal dağılıma uyan DF, DFYí, vWF ölçümlerinin karşıșşıımasında "student-t" ve normal dağllıma uymayan fibrinojen ve hsCRP ölçümlerinin karşılaştırmasında "Mann-Whitney U" testi kullanıldı. Ayrıca DF, serbest ve toplam DFYI, fibrinojen, vWF ve hsCRP'nin ailesinde erken koroner kalp hastalığı olma üzerine etkisi çok değişkenli, geriye dönük, adımsal lojistik regresyon yöntemiyle incelendi. Veriler ortalama \pm standart sapma olarak ifade edildi. P değerinin 0,05 'in altında olması istatistiksel olarak anlamlı kabul edildi.

\section{Sonuçlar}

Her iki gruptaki olguların 14'ü erkek (\%32,6) ve 29'u kızdı $(\% 67,4)$. Çalışma ve kontrol grubundaki çocukların yaşları 5-18 yıl arasında değişmekte idi. Çalışma ve kontrol grubunda ortalama yaş 13,3 $\pm 3,6$ yıl (en düşük: 5 , en yüksek: 18, ortanca: 14 yıl) idi. Çalışma ve kontrol grubunun vücut ölçüm ve kan basıncı değerleri arasında istatistiksel olarak anlamlı fark saptanmadı ve Tablo 1'de özetlendi. Ağırlık ve

Tablo 1. Çalışma ve kontrol gruplarının vücut ölçüleri ve kan basıncı değerleri

\begin{tabular}{|c|c|c|c|c|}
\hline & Grup & $\mathbf{n}$ & Değer & $\mathbf{p}$ \\
\hline Ağırlık (kg) & $\begin{array}{l}\text { Çalışma } \\
\text { Kontrol }\end{array}$ & $\begin{array}{l}43 \\
43\end{array}$ & $\begin{array}{l}50,2 \pm 15,9(17-86,49) \\
50,7 \pm 3,6(15,4-85,51)\end{array}$ & $A D$ \\
\hline Boy (cm) & $\begin{array}{l}\text { Çalışma } \\
\text { Kontrol }\end{array}$ & $\begin{array}{l}43 \\
43\end{array}$ & $\begin{array}{l}153 \pm 17(106-179,159) \\
154 \pm 19(103-179,159)\end{array}$ & $A D$ \\
\hline Vücut kitle indeksi $\left(\mathrm{kg} / \mathrm{m}^{2}\right)$ & $\begin{array}{l}\text { Çalışma } \\
\text { Kontrol }\end{array}$ & $\begin{array}{l}43 \\
43\end{array}$ & $\begin{array}{c}21,0 \pm 4,14(13,5-30,8,21,2) \\
20,6 \pm 4,1(12,8-30,5,21,6)\end{array}$ & $A D$ \\
\hline Sistolik kan basıncı (mmHg) & $\begin{array}{l}\text { Çalışma } \\
\text { Kontrol }\end{array}$ & $\begin{array}{l}43 \\
43\end{array}$ & $\begin{array}{l}115,3 \pm 12,2(89-149,114) \\
115,8 \pm 10,0(89-138,120)\end{array}$ & $A D$ \\
\hline Diyastolik kan basıncı (mmHg) & $\begin{array}{l}\text { Çalışma } \\
\text { Kontrol }\end{array}$ & $\begin{array}{r}43 \\
43\end{array}$ & $\begin{array}{c}69,4 \pm 8,6(54-84,70) \\
70,1 \pm 8,1(54-85,75)\end{array}$ & $A D$ \\
\hline
\end{tabular}

Sonuçlar ortalama \pm standart sapma (en düşük-en yüksek, ortanca) olarak verilmiştir. AD: Anlamlı değil 
vücut kitle indeksi hesaplandığında çalıșma grubunda dört $(\% 9,3)$, kontrol grubunda üç çocuk $(\% 6,9)$ fazla tartılı veya şişman olarak belirlendi. Sistolik kan basıncı ve diyastolik kan basıncı yaşa göre değerlendirildiğinde çalıșma grubunda üç $(\% 6,9)$, kontrol grubunda iki çocukta $(\% 4,6)$ hipertansiyon saptandı (>\%95 persantil). Çalışma ve kontrol grupları arasında DF, DFYi, fibrinojen, hsCRP açısından anlamlı fark saptanmazken, çalışma grubundaki vWF değerleri $(116,3 \pm 52,2 \mathrm{ng} / \mathrm{mL})$, kontrol grubuna $(86,8 \pm 41,4 \mathrm{ng} / \mathrm{mL})$ göre daha yüksek bulundu $(p<0,05)$. Çalsşma ve kontrol grubunun DF, serbest ve total DFYl, fibrinojen ve vWF düzeyleri, karşılaştırması ve normal değerleri Tablo 2'de özetlenmiştir. Araştırmamızda alınan plazma örneklerinde belirlenen vWF değerleri çalsşma grubunda $116,3 \pm 52,2 \mathrm{ng} / \mathrm{mL}$ (en düșük: 31 , en yüksek: $283 \mathrm{ng} / \mathrm{mL}$ ), kontrol grubunda $86,8 \pm 41,4 \mathrm{ng} / \mathrm{mL}$ (en düşük: 11, en yüksek: $197 \mathrm{ng} / \mathrm{mL}$ ) idi. Çalışma grubundaki vWF değerleri, kontrol grubuna göre daha yüksek saptandı $(p<0,05)$. Çallşma grubunda 12 örnekte, kontrol grubunda bes örnekte vWF değerleri yüksek olarak belirlendi. Araștırmada ayrıca DF, serbest ve toplam DFYi, fibrinojen, vWF ve hsCRP'nin ailesinde $\mathrm{KAH}$ olma üzerine etkisi çok değişkenli, geriye dönük, adımsal lojistik regresyon yöntemiyle incelendi. Doku faktörü, serbest ve total DFYi, fibrinojen ve hsCRP'nin ailesinde erken yașta KAH olmayı bağımsız risk etmeni olarak etkilemediği, vWF'nin yüksek

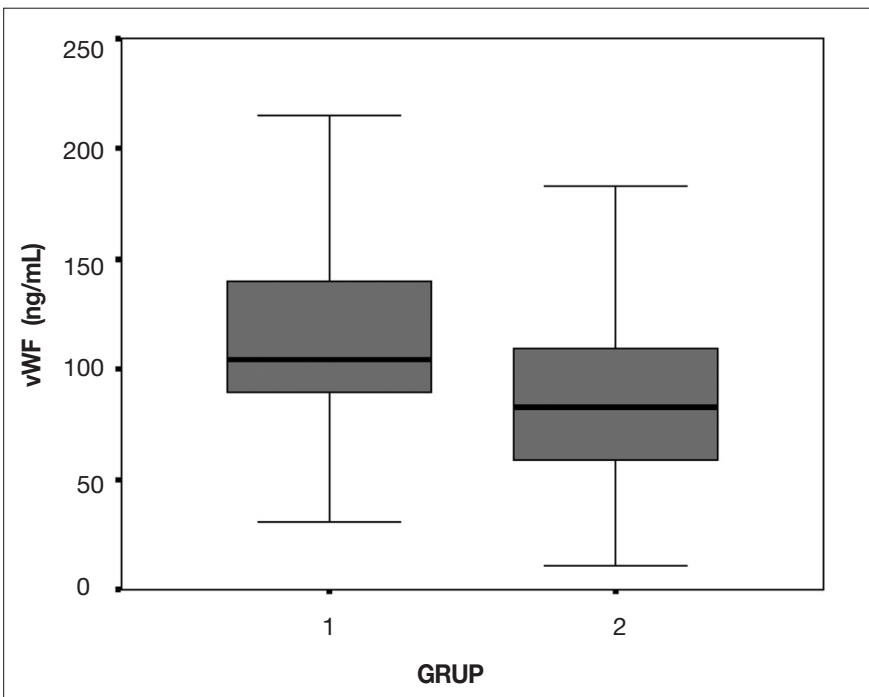

Şekil 1. Çalışma ve kontrol grubundaki olguların vWF değerleri olmasının ise bağımsız risk etmeni olarak etkili olduğu bulundu [OR: 1,017 (\%95 güven aralığında 1,005-1,0029)]. $\mathrm{Bu}$ istatistiksel veri vWF'nin değerinin $1 \mathrm{ng} / \mathrm{mL}$ artmasının, ailesinde erken yașta KAH olma olasılığını \%1,7 artırdığı anlamına gelmektedir.

\section{Tartışma}

Ailesinde erken yașlarda KAH öyküsünün varlığı, bu hastalığın gelişimi için daha büyük risk etmeni olarak kabul edilmektedir (6). Bu durumun riski artırma mekanizması tam olarak bilinmemekle birlikte ateroskleroza eğilim, tromboza eğilim, enflamasyon olası nedenlerdir (7). Koroner arter hastalığına yol açan aterosklerozda anjiyopatiden daha önce olușan endotel hasarı, subklinik aterosklerozun en erken belirtisi ve kritik basamağıdır (8). Enflamasyonu, büyüme faktörlerini, hücre adezyonunu, trombozu ve altındaki düz kasın vasküler tonusunu düzenleyen dolaşımsal sinyalleri endotel hücreleri üretir. Endotelden salınan tromboz ve fibrinolizi düzenleyen hemostatik değișkenlerin artıșı, endotelin hasar veya işlev bozukluğunun bir göstergesi olarak düşünülmektedir (9). Bu nedenle birçok araştırmacı ateroskleroza, dolayısı ile KAH'a yol açacak endotel işlev bozukluğunu göstermede özel belirteçler aramışlardır. Trombomodülin, vWF, DF, DFYi bunlardan birkaçıdır (9-11). Bu çalışma kapsamında ailesinde erken yaşta $\mathrm{KAH}$ olan çocuklarda endotel hasar göstergesi olarak DF, DFYI, vWF ve fibrinojen ile enflamasyon göstergesi olan hsCRP incelenmiștir.

Bu çalıșmanın en önemli sonucu ailesinde 55 yașın altında KAH öyküsü olan çocuklarda vWF'nin yüksek olduğu ve bu belirtecin KAH'ı öngörmede belirleyici olarak kullanabileceğidir. Von Willebrand faktör akım stresi fazla olan kapilerlerde hemostaz için gereken, eksikliğinde mukozada kanama eğilimi yaratan önemli bir kan elementidir. Kandaki vWF düzeyinin yüksekliği ise tromboza eğilim yaratır. Ayrıca vWF'nin yüksek olması ateroskleroz oluşumunda önemli bağımsız bir belirteç olarak değerlendirilmektedir. Yüksek akım stresi olan arteriyel bileșkelerde vWF'nin aterom plak oluşumunu hızlandırdığı gösterilmiştir (12). Von Willebrand faktörünün tromboz oluşumunda ve aterosklerozdaki bu önemli rolünün yanı sıra çalışmamıza göre ailesinde erken yaşta KAH olan çocuklarda da yüksek saptanması, erken yaşta başlayan ateroskleroz sürecinin ilk belirteçlerinden biri olarak açıklanabilir. Ölümden sonraki çalışmalarda da

Tablo 2. Çalışma ve kontrol grubunun DF, serbest ve toplam DFYi, fibrinojen ve vWF düzeyleri ve karşılaştırması

\begin{tabular}{|l|c|c|c|c|}
\hline & Çalışma grubu & Kontrol grubu & Normal değerler & p \\
\hline DF $(\mathrm{pg} / \mathrm{mL})$ & $137,9 \pm 59,6$ & $131,8 \pm 47,4$ & $\mathrm{AD}$ & $0-150$ \\
\hline Toplam DFYi $(\mathrm{ng} / \mathrm{mL})$ & $64,0 \pm 15,0$ & $68,2 \pm 15,8$ & $\mathrm{AD}$ & $0-100$ \\
\hline Serbest DFYi $(\mathrm{ng} / \mathrm{mL})$ & $19,2 \pm 4,5$ & $20,5 \pm 4,7$ & $\mathrm{AD}$ & $\mathrm{AD}$ \\
\hline Fibrinojen $(\mathrm{mg} / \mathrm{L})$ & $251,8 \pm 71,1$ & $243,0 \pm 56,0$ & $200-400$ \\
\hline vWF $(\mathrm{ng} / \mathrm{mL})$ & $116,3 \pm 52,2$ & $86,8 \pm 41,4$ & $<0,05$ & $0-100$ \\
\hline hsCRP $(\mathrm{mg} / \mathrm{L})$ & $1,1 \pm 1,2$ & $1,2 \pm 1,2$ & $\mathrm{AD}$ & 0,5 \\
\hline
\end{tabular}

AD: Anlamlı değil, hsCRP: Yüksek duyarıklı C-reaktif protein, DF: Doku faktörü, DFYi: Doku faktörü yolu inhibitörü, vWF: von-Willebrand faktör 
aterosklerozun çocukluk döneminde başladığı, birinci on yılın sonunda arterlerde yağlı çizgilenmelerin görüldüğü ve annede hiperkolesterolemi olduğunda yağlı çizgilenmelerin intrauterin yaşamda bile var olduğu bilinmektedir (13). Çalışmamızın sonuçlarına göre aterosklerozun erken belirtisi olarak vWF'nin kullanılabileceği kanısına varıldı. Oysa Makris ve ark.'ları (14) çalışmamıza benzer şekilde oluşturdukları hasta grubunda babalarında 55 yaşın altında miyokard enfarktüsü (ME) öyküsü olan çocuklarda, sağlıklı kontrollere göre vWF'yi farklı bulmamışlardır. Ancak yalnızca babalarında ME olan çocukların çalışmaya alınması ve kontrol grubunun uygun ve yeterli seçilememesi ile iki çalışmanın sonuçlarının farklı̆̆ını açıklayabilir. Buna karşın son yıllarda yapılan başka iki araştırmada ME geçirenlerin çocuklarında FVII ve FXII, fibrinojen, tPAI ile birlikte vWF'yi kontrol grubuna göre yüksek bulmuşlardır. Ancak bu iki çalışmanın yönteminde ebeveynlerin KAH geçirme zamanı dikkate alınmamıştır (15). Von Willebrand faktörünün kan düzeyi normalde \%40-\%200 arasındadır. Kan grubu 0 olan bireylerde vWF düzeyinin \%25 oranında daha düşük olduğu bildirilmiştir (16). Yaş ilerledikçe kan düzeyinde artış görülür. Beta adrenerjik uyarılarla, steroid tedavisi ile gebelikte, enflamatuvar hastalıklarda, aterosklerozda, diyabetes mellitusta, böbrek ve karaciğer hastalıklarında ve vaskülitlerde vWF düzeyinin yükseldiği gösterilmiştir (12). Çalışmamızın önemli bir kısıtlıı̆ı çalışma ve kontrol grubundakilerin kan grubu kaydını almamamızdı. Çalışma ve kontrol gruplarımızı oluşturan hiçbir çocukta vWF'yi artıran kronik hastalık ve ilaç kullanımı öyküsü yoktu.

Araştırmamızda ailesinde erken yaşta $\mathrm{KAH}$ olan ve olmayan gruplar arasında fibrinojen düzeyleri arasında farkllık saptanmadı. Fibrinojen pıhtılaşmada en önemli yapı taşlarından biridir. Aktifleşen trombosite bağlanarak kümelenmeyi kolaylaştııı, fibrin oluşumunu başlatır, plazma yoğunluğunu artıır, ayrıca enflamatuvar durumlarda da fibrinojen yüksektir (17). Fibrinojen yüksekliği $\mathrm{KAH}$, tekrar eden kardiyak olaylar, ME'den ölüm için risk etmeni olarak belirlenmiş, KAH'ın risk etmenleri olan sigara içme, şişmanlık, DM ve dislipidemi ile fibrinojen yüksekliği arasında olumlu ilişki bulunmuştur (18). Bizim çalışmamızın sonuçlarına karşın, Makris ve ark.'ları da (14) yaptıkları çalışmada babalarında 55 yaşın altında ME öyküsü olan çocuklarda, sağlıklı kontrollere göre fibrinojeni yüksek bulmuşlardır. Buna karşılık, çalışmamızın sonuçlarına benzer şekilde Shea ve ark.'ları (19) ile Pitsavos ve ark.'ları (20) KAH aile öyküsü olanlarda, plazma fibrinojenini kontrol grubunda yüksek saptamamışlardır.

Araşıırmalar, koroner arterdeki hassas aterosklerotik plağın zayıf fibröz şapkasının rüptürü ile akut koroner trombozun oluştuğunu göstermiştir. Bu durumda kana karışan DF, FVII/VIla'ya bağlanarak pıhtılaşmayı başlatır (21). Koroner lezyonun en trombojenik bileşeni olan plağın lipitten zengin nekrotik merkezi, DF'nin çok fazla olduğu bölgedir. Doku faktörünün FVIla'ya bağlanması trombin oluşumuna neden olarak, trombosit aktivasyonunu uyarır ve fibrin olușumu ile koroner arterlerde kısmi veya tam tıkanma sonucu KAH, ME veya kararsız anjina oluşur (22). Artmış dolaşan DF ile oluşan tromboz, DM, sigara, hiperlipidemi, hipertansiyon ile birlikte kardiyovasküler risk etmeni olarak kabul edilmektedir (23). Çalışmamızda DF ve DFYi değerlerini, ailesinde erken dönemde kalp hastalığı öyküsü olan çocuklarda, sağlıklı kontrollere göre farklı bulmadık. Pıntılaşma sisteminin aktive olmasındaki çağdaş görüşün temelinde, DF salınım veya belli hücre yüzeylerinde ekspresyonunun artması yer alır. Bu nedenle DF yolunun dizginlenmesi kanın akış dengesi için çok önem kazanmaktadır. Pıhtılaşma sisteminde DF aracilı̆ıyla başlayan ve az miktarda fibrin oluşumu ile sonlanan ilk pıhtılaşma aktivasyonu, endotelden salınan DFYi aracılığı ile engellenir. Yani DFYI, DF ile oluşan pıhtılaşmanın ana inhibitörüdür. Doku faktörü yolu inhibitörü; FXa'yı doğrudan inhibisyonunun haricinde FXa varlığında DF-FVIla birleşimine negatif geriye dönüşümlü inhibisyon yapar $(24,25)$. Damar endoteli DFYI'nin başlıca kaynağıdır ve damarda dolaşan DFYI'nin \%50-80'i endotelde saklanır. İnsanlarda ve invitro çalışmalarda, aterosklerotik plaktaki azalmış DFYi bulunması, aterosklerotik lezyondaki arteriyel trombozu azaltmada DFYI'nin DF yolunun bölgesel inhibisyonunda oldukça başarıı olduğu sonucuna varımıştır (25).

Doku faktörü yolu inhibitörünün, DF'yi engellemenin ötesinde lipoprotein biyokimyasında da etkili olduğu araştııımıştır. Doku faktörü yolu inhibitörünün lipoprotein lipaz aktivitesini artırdığı ve bu yolla trigliserit hidrolizini de artırdığı belirlenmiştir (26). Brodin ve ark.'ları (26) VLDL uyarısından 10 dakika sonra DFYi RNA'sının artmaya başladığııı, endotel hücresine bağlanan VLDL ve lipoprotein lipaza yanıt olarak DFYl'nin salındığı sonucuna ulaşmışlardır.

Çalışmamızın farklıı̆ı KAH'da çok defa araştııılan DF ve DFYi'nin, ailesinde erken yaşta $\mathrm{KAH}$ olan yakınmasız çocuklarda ilk kez değerlendirilmesidir. Çalışma ve kontrol grupları arasında fark saptanmaması, gelişen aterosklerotik süreçte bu hastalarda olabilecek patofizyolojik değişikliklerde DF ve DFYI'nin henüz değişmemiş olması ile açıklanabilir. Yeni çalışmalarda DFYl'nin antikoagülan aktivitesi ölçülebilmektedir ve sağlıklı bireylerde DFYl'nin antikoagülan aktivitesi ile serbest DFYl'nin kuvvetli uyum gösterdiği bildirilmiştir (27). $\mathrm{Bu}$ yeni ölçüm KAH'da ve KAH gelişim riski yüksek bireylerde araştırılmaya devam etmektedir.

Son yillarda ateroskleroz ile enflamasyon arasındaki ilişkinin tam olarak aydınlatıması, dolaşımdaki bazı enflamatuvar belirteçlerin kardiyovasküler olay gelişme riskini belirlemede yol gösterici olarak kullanılabileceği düşüncesini doğurmuştur (28). Bu belirteçler arasında en yoğun kanıtlar CRP ile ilişkilidir. Bilinen bir kalp hastalığı olmayan kişilerde ve $\mathrm{KAH}$ ile başvuran hastalarda gelişebilecek kalp olaylarını belirlemede CRP'nin yeri olduğunu gösteren çok sayıda veri bulunmaktadır. Orta derecede veya yüksek CRP değerleri, diğer risk etmenlerinin varlığından bağımsız olarak artmış kardiyovasküler olay riskine eşlik etmektedir. C-reaktif protein aterosklerotik plak içerisinde düz kas hücresi ve makrofajlarca da üretilir ve bu da aterosklerotik plağın 
duyarlılaşmasında ve rüptüründe rol oynar. C-reaktif protein ayrıca; dolaşan monositleri aktive ederek plak yakınına çeker, endotel işlevlerinin bozulmasına katkıda bulunur, sitokin salınımı ve kompleman sisteminin aktivasyonunu sağlar, hücre dışı matriksin yeniden düzenlenmesini (remodeling) kolaylaştııı. Doku faktörü sentezinin uyarılması ile trombotik olayın başlamasını da CRP sağlar. İnterlökin I, 6, 18, CD40/CD40 kompleksi de CRP gibi ateroskleroz plağının zayiflamasında ve trombozunda önemli rol oynar. Bu sitokinler bölgesel ve sistemik olarak etki ederler. Bu karmaşık bilmece sonucunda KAH'da monosit ve nötrofillerden, dolaşan trombositlerden, endotel hücrelerinden veya aterosklerotik plağın kendisinden, enflamatuvar yanıta karşı salınan DF'nin plazma miktarı artar $(28,29)$.

C-reaktif protein artışı damar duvarında artmış enflamatuvar durumun göstergesidir. Birçok risk etmeni olan KAH'lı hastalarda CRP artışı tekrarlayan iskemi, ME ve ani kalp ölümü belirtecidir (29). Çalıșmamızda ailesinde erken yaşta $\mathrm{KAH}$ öyküsü olan çocuklarda hsCRP'yi sağlıklı kontrollere göre farklı bulmadık. Bu durum yeni gelişen aterosklerotik süreçte hsCRP'nin henüz artmadığını, yani damar duvarındaki enflamasyonun ateroskleroza henüz katkı sağlamadığını gösterebilir.

Ailesinde erken yașta KAH öyküsü olan çocuklarda yaptığımı bu çalıșmada, erken yaș olarak 55 yaş seçilmiştir. Bu konuda yapılmış çoğu çalışmada erken yaș sınıı olarak bizim gibi 55 yaş seçilirken (30-32), Mansur ve ark.'ları (5) 45, Jomini ve ark.'ları (33) erkekte 50 yaşı, kadında 55 yaşı, Hauser ve ark.'ları (34) ise erkeklerde 51 yaşı, kadınlarda 56 yaşı, Amerikan Kolesterol Eğitim Programı ise erkekte 55 yaşı, kadında 65 yaşı seçmiştir (17). Erken yaş olarak 55 yaşından daha düşük eşik belirlemek, özellikle 45 yaş ve altında KAH olan hastaların çoğunda ailevi hiperkolesterolemi olabileceğinden uygun değildir. Daha yüksek yaşlarda riski artıran erken yaş durumu özelliğini kaybeder. Bu nedenle biz de literatürle uyumlu olarak 55 yaşı sınır olarak kabul ettik.

Araștırmamızın bir kısıtlıı̆ı risk etkeni olarak sadece aile öyküsü kullanımasıdır. İleriye dönük çalışmalarda aynı belirteçlerin şişmanlık, hiperlipidemi, diyabet gibi birden fazla risk etkeni taşıyan gruplarda çalışılması ve toplam riskin belirlenmesi yararlı olabilir (35).

Çalışmamızda ailesinde erken yaşta $\mathrm{KAH}$ öyküsü olan çocuklarda hemostatik belirteçlerden DF, serbest ve toplam DFYI, fibrinojen ve enflamatuvar belirteçlerden hsCRP'yi sağlıklı kontrollere göre farklı bulmadık. Bu durum yeni gelişen aterosklerotik süreçte bu belirteçlerin henüz artmadığını, yani damar duvarındaki enflamasyon ve trombotik sürecin ateroskleroza henüz katkıda bulunmadığını düşündürdü. Von Willebrand faktör ise erken aterosklerotik hastalığı öngörmede belirteç olarak kullanılabilir. Bu konuda geniş çaplı, ileriye dönük, rastgele çalışmalara gereksinim vardır. İleride çalışmamıza benzer araştırmalarda saptanabilecek yeni risk belirteçleri bulunduğunda, KAH gelişimi daha önceden belirlenebilecek ve risk altındaki bu çocukların yaşam biçimi değiştirilerek ve tedavi seçenekleri uygulanarak $\mathrm{KAH}$ gelişimi önlenebilecektir.

\section{Çıkar çatışması: Bildirilmedi.}

\section{Kaynaklar}

1. Starc GTJ. Management of hyperlipidemia in children. Ped Card 2001; 12: 205-13. (Abstract) / (Full Text) / (PDF)

2. Onat A, Keleș I, Çetinkaya A, ve ark. On yıllık TEKHARF çalışması verilerine göre Türk erişkinlerinde koroner kökenli ölüm ve olayların prevalansı yüksek. TKD 2001; 29: 8-19.

3. Reis EC, Kip KE, Marroquin OC, et al. Screening children to identify families at increased risk for cardiovascular disease. Pediatrics 2006; 118: 1789-97. (Abstract) / (PDF)

4. Murabito JM, Nam BH, D'agostino RB, Lioyd-Jones DM, O'Donnell CJ, Wilson WF. Accuracy of offspring reports of parental cardiovascular disease history: The Framingham offspring study. Ann Intern Med 2004; 140: 434-40. (Abstract)

5. Mansur AD, Mattar APL, Rolim AL, et al. Distribution of risk factors in parents and siblings of patients with early coronary artery disease. Arq Bras Cardiol 2003; 80: 582-4. (Abstract) / (Full Text)

6. Nasir K, Michos ED, Rumberger JA, et al. Coronary artery calcification and family history of premature coronary heart disease. Sibling history is more strongly associated than parental history. Circulation 2004; 110: 2150-6. (Abstract) / (PDF)

7. Gaeta G, De Michele M, Cuomo S, et al. Arterial abnormalities in the offspring of patients with premature myocardial infarction. N Engl J Med 2000; 343: 840-6. (Abstract) / (Full Text) / (PDF)

8. Chara M, Tousoulis D, Stefanadis C. Early atherosclerosis in children. Diagnostic approaches and therapeutic strategies. Intern J Cardiol 2005; 109: 152-9. (Abstract) / (Full Text) / (PDF)

9. Rigla M, Mateo J, Fontjuberta J, Souto JC, Leiva A, Perez A. Normalization of tissue factor pathway inhibitor activity after glycemic control optimization in type 1 diabetic patients. Thromb Haemost 2000; 84: 223-7. (Abstract)

10. Onat A, Hergenc G, Yıldırım B, ve ark. Türk eriškinlerde kanda fibrinojen düzeyleri ve bazı risk parametreleri ile ilişkileri. TKD 2000; 28: 115-20. (Abstract)

11. Al-Nozha MM, Abdel-Gader AM, Arafah MR, Al-Maatouq MA Al-Shahid MS, Al-Harthi SS. Tissue factor pathway inhibitor, natural coagulation inhibitors and hemostatic activation markers in patients with acute coronary syndromes. Saudi Med J 2005; 26: 937-42. (Abstract)

12. Gürsel T. Von willebrand hastalı̆ı̆ Türk toplumundaki prevalansı, kliniği ve genetik özellikleri. II. Ulusal Tromboz, Hemostaz ve Anjioloji Kongresi. Kasım, Türkiye, İstanbul; özet kitabı: 2001:29-32.

13. Napoli C, Glass CK, Witztum JL, et al. Influence of maternal hypercholesterolaemia during pregnancy on progression of early atherosclerotic lesions in childhood: fate of early lesions in children (FELIC) study. Lancet 1999; 354: 1234-41. (Abstract) / (Full Text) / (PDF)

14. Makris TK, Hatzizacharias AN, Krespi PG, et al. Markers of risk in young offspring with paternal history of myocardial infarction. Intern J Cardiol 2003; 89: 287-93. (Abstract) / (Full Text) / (PDF)

15. Pankow JS, Folsom AR, Province MA, et al. Family history of ischemic heart disease and hemostatic variables in middle aged adults. Thromb Haemost 1997; 77: 87-93. (Abstract)

16. Nathan DG, Orkin SH. Nathan and Oski's Hemotology of Infancy and Childhood. $5^{\text {th }}$ edition, volume 2. Philedelphia: WB Saunders Company, 2002; 1631-59.

17. Robinson DM, Schwahn C, Alte D, John U, Felix SB, Völzke H. Plasma fibrinogen levels are associated with a strong family history of myocardial infarction. Blood Coagul Fibrinolysis 2004; 15:4 97-502. (Abstract) 
18. Wilhemsen L, Svardsudd K, Korsan-Bengtien K, Larson B, Welin L, Tibblin G. Fibrinogen as a risk factor for stroke and myocardial infarction. New Engl J Med 1984; 311: 501-5. (Abstract)

19. Shea $S$, Isasi $C R$, Couch $S$, et al. Relations of plasma fibrinogen level in children to measures of obesity, the (G-455-->A) mutation in the beta-fibrinogen promoter gene, and family history of ischemic heart disease: the Columbia University BioMarkers Study. Am J Epidemiol 1999; 150: 737-46. (Abstract) / (PDF)

20. Pitsavos C, Skoumas J, Dernellis J, et al. Influence of biological factors on lipid and fibrinogen measurements in young men. An epidemiological study in 2009 recruits. Eur Heart J 1998; 19 : 1642-7. (Abstract) / (Full Text) / (PDF)

21. Mackman N. Role of tissue factor in hemostasis thrombosis and vascular development. Athroscler Thromb Vasc Biol 2004; 24: 1015-22. (Abstract) / (Full Text) / (PDF)

22. Fuster V, Moreno PR, Fayad ZA, Corti R, Badimon JJ. Atherothrombosis and high risk plaque. J Am Coll Cardiol 2005; 46: 937-54. (Abstract) / (PDF)

23. Sambola A, Osende J, Hathcock J, et al. Role of risk factors in the modulation of tissue factor activity and blood thrombogenicity. Circulation 2003; 107: 973-7. (Abstract) / (Full Text) / (PDF)

24. Morange PE, Blankenberg S, Alessi MC, et al. Atherogene Investigators. Prognostic value of plasma tissue factor and tissue factor pathway inhibitor for cardiovascular death in patients with coronary artery disease: the AtheroGene study. J Thromb Haemost 2007; 5: 475-82. (PDF)

25. Caplice NM, Mueske CS, Kleppe LS, Simari RD. Presence of tissue factor pathway inhibitor in human atherosclerotic plaques is associated with reduced tissue factor activity. Circulation 1998; 98: 1051-7. (Abstract) / (Full Text) / (PDF)

26. Brodin E, Iversen N, Hansen JB. Impact of native VLDL on tissue factor pathway inhibitor in endothelial cells and interactions between TFPI and lipoprotein lipase. J Lab Clin Med 2006; 147: 167-73. (Abstract) / (Full Text) / (PDF)
27. Dahm AE, Andersen TO, Rosendaal F, Sandset PM. A novel anticoagulant activity assay of tissue factor pathway inhibitor I (TFPI). J Thromb Haemost 2005; 3: 651-8. (Abstract) / (Full Text) / (PDF)

28. Rost NS, Wolf PA, Kase CS, et al. Plasma concentration of C-reactive protein and risk of ischemic stroke and transient ischemic attack: the Framingham study. Stroke 2001; 32: 2575-9. (Abstract) / (Full Text) / (PDF)

29. Margaglione M, Cappucci G, Colaizzo D, Vecchione G, Grandone E, Di Minno G. C-reactive protein in offspring is associated with the occurrence of myocardial infarction in first-degree relatives. Arterioscler Thromb Vasc Biol 2000; 20: 198-203. (Abstract) / (Full Text) / (PDF)

30. Samani $\mathrm{NJ}$, Burton $\mathrm{P}$, Mangino $\mathrm{M}$, et al. A genomewide linkage study of 1933 families affected by premature coronary artery disease. The British Heart Foundation (BHF) Family Heart Study. Am J Hum Genet 2005; 77: 1011-20. (Abstract)

31. Antal M, Regoly-Merei A, Mesko E, et al. Incidence of risk factors in parents with acute myocardial infarction at young age and in their children. Orv Hetil 2004; 145: 2477-83. (Abstract)

32. Kelishadi R, Zadegan NS, Nadery GA, Asgary A, Bashardoust $N$. Atherosclerosis risk factors in children and adolescents with or without family history of premature coronary artery disease. Med Sci Monit 2002; 8: 425-9. (Abstract)

33. Jomini V, Oppliger-Pasquali S, Wietlisbach V, et al. Contribution of major cardiovascular risk factors to familial premature coronary artery disease: the GENECARD Project. J Am Coll Cardiol 2002; 40: 676-84. (Abstract) / (PDF)

34. Hauser ER, Crossman DC, Granger CB, et al. Genomewide scan for early-onset coronary artery disease in 438 families. The GENECARD Study. Am J Hum Genet 2004; 75: 436-47. (Abstract) / (Full Text) / (PDF)

35. Guran O, Akalın F, Ayabakan C, Dereli FY, Haklar G. High sensitivity $\mathrm{C}$-reactive protein in children at risk for coronary artery disease. Acta Paediatr 2007; 96: 1214-9. (Abstract) / (Full Text) / (PDF) 